DOI: https://doi.org/10.3126/njdrs.v18i01.41947

\title{
Media Framing of COVID- 19: A Content Analysis of Nepali Newspapers
}

\author{
Sudhamshu Dahal, PhD $^{1}$, Bishnu Bahadur Khatri ${ }^{2}$ \\ ${ }^{1}$ Assistant Professor at Department of Languages and Mass Communication \\ School of Arts, Kathmandu University, Nepal \\ Email:s.dahal@ku.edu.np \\ ${ }^{2}$ Associate Professor at Central Department of Rural Development \\ Tribhuvan University, Nepal \\ Correspondence should be addressed toBishnu Bahdur Khatri; bishnu.khatri@cdrd.tu.edu.np, \\ https://orcid.org/0000-0003-4777-1307
}

\begin{abstract}
The COVID-19 pandemic has spread across the globe, posing a major and alarming public health concern. This has been due, in part, to the increasing number of infected population day by day. Also, media coverage appeared to be one of the influencing factors to the opinion formation of COVID-19 issues. Since the whole world is still reeling under the effect of COVID-19 pandemic. At this juncture, the content and tone of the newspaper is still unknown. Therefore, the paper tries to assess critically about the media effect in reporting of the COVID-19 pandemic. This study has a significant practical relevance during this period. Furthermore, the study contributes to scientific knowledge about the use of frames and tones in media coverage with regard to pandemic. For this purpose of content analysis, two popular Nepalese English language newspapers; The Kathmandu Post (privately owned media) and The Rising Nepal (state-owned media) were purposively selected on basis of their ownership and coverage. The content and tone of the media coverage with regard to the pandemic from May 2020 until the end of July 2020 was investigated. The results showed that the media coverage was most frequently done in terms of economic crisis rather than covering the pandemic as a health crisis. Furthermore, the tone of the media coverage of the pandemic is more negative in the privately owned media than the state-owned media.

However, both the newspapers have covered the majority of articles through the economic framing rather than health.
\end{abstract}

Key words: COVID- 19, Pandemic, framing, content, tone, media coverage, newspapers

\section{Introduction}

On March 11, 2020, the World Health Organization (WHO) declared the spread of coronavirus disease (COVID- 19) as a global health crisis and confirmed it as a pandemic of global scale. At that time, there were more than 118,000 cases in 114 countries, and 4,291 people had already succumbed to the disease. Of the 118,000 cases in 114 countries reported globally, more than 90 percent of cases were just in four countries(WHO, 2020).Meanwhile, 81 countries had not reported a single case of COVID-19, while 57 countries had reported 10 cases or less (CDC,2020). The pandemic is of the coronavirus family that ravages the whole world, is a new strain of the virus which has not been found in humans previously. The virus was identified in Wuhan, which is the capital of Hubei Province in China in December 2019. The virus initially transmitted to the people from an animal source. Analysis of the outbreak revealed the virus 
was distinct from SARS-Cov, but the genetic similarity was found in a virus that was isolated from the bats (CDC, 2020).

The symptoms of the coronavirus include cough, fever, shortness of breath and diarrhoea. However, there have been various instances of viruses showing different signs that one didn't expect, like muscles aches, chills, sore throat, chest pain, gastrointestinal symptoms, loss of smell or taste, skin changes etc(CDC, 2020). What had started merely as an infection from a wildlife market of Wuhan in China got spread across the countries after countries in months, and the outbreak would be the most significant health crisis the world had witnessed since Spanish flu of 1918 (CDC,2018). The global pandemic naturally brought the global economy down to a point, which was beyond the 2008-09 global recession; millions lost their jobs and economic activities remained suspended for months (ILO, 2020).

The pandemic travelled across the continents and left tens of thousands infected and left the global health facilities in shambles (WHO,2020). Countries imposing travel restrictions by sealing its borders and enforcing severe lockdowns, extending for several weeks, left the common public struggling for basic needs and languishing to make their dead ends meet (OECD, 2020). While every other sector came under the grip of the global pandemic, which had begun from December 2019, the media could not remain untouched.

According to a National Survey Report on impact of COVID-19 on Journalism in Nepal (PCN, 2020) stated that the COVID-19 hit the mass media on two fronts. First, they were burdened with reporting of the global pandemic like any other crisis or natural calamities, going out and risking their lives. Secondly, their operation was severely affected as most of the media had to lay off their regular staff following the financial troubles induced by the pandemic and most of them also had to make changes in their day-to-day business. As per the survey, $83 \%$ of journalists reported increased vulnerability, $75 \%$ increased anxiety and $62 \%$ grief (ibid.). However, the media has remained an essential agent in the event of a health epidemic in the 21st century. This was even seen during the SARS, MERS, Ebola and now COVID-19. Information about infectious diseases that involve unanticipated outbreaks causes severe economic, physical, psychological, and social impact (Ophir, 2018). These functions make the media apart as an essential link or factor during the pandemic and virus outbreak to bridge the communication gap between the general public and the government regarding health emergencies.

To that end, this article examines how major Nepali news media framed the COVID-19 crisis. From informing the general people about the pandemic, the media also strive to shape public opinion and perception, measures to be taken to mitigate (flatten the curve) viruses through reports, videos and using other means of communication. (Nisbet, 2009) states that the framing constitutes an important part of the media that contributes to shaping the audience perception and societal disposition to events covered by the media. Thus, the public response to the virus and whether to take precautionary measures or not depends upon how the media frame the pandemic. The public response to the virus and whether to take precautionary measures or not depends upon how the media frame the pandemic. As such media could either mitigate or accentuate the crisis depending on the significant frames adopted for the coverage. In this context, this article presents a comparative framing analysis of news coverage by Rising Nepal, a state-owned media and The Kathmandu Post, a privately owned broadsheet dailies, while covering the COVID-19 pandemic. This article is delimited to the study newspaper frames and not the audience's perspectives of the issues.

In Nepal the number of infections has been significant and so are the deaths. According to the Ministry of Health and population's COVID-19 portal, Nepal has already reported more than 11,500 death toll and more than 800000 infections as of 28 December 2021(https://covid19.mohp.gov.np/ accessed on 28.12.2021). Thus, there is a more significant role of the media during such an unprecedented time of pandemic to inform people about the situations. The fact that no empirical study on the novel coronavirus outbreak from Nepal on the framing by newspaper during pandemic was found for the literature, this article aims to fill the identified gap as it would allow us to examine how Nepali media may frame a disease when facing an infectious disease. 
Within this context, it is apparent to understand that one way of keeping in touch with the contemporary world is through the media. While media can play a dynamic role in handling the issues, it becomes imperative to examine the framing of the COVID-19 pandemic. Entman (1993) argues that to frame an issue is to "select some aspects of perceived reality in such a way as to promote a particular problem definition, causal interpretation, moral evaluation or treatment recommendation for the item described" (p. 52). He further argues that framing involves "selecting and highlighting some facets of events or issues, and making connections among them so as to promote a particular interpretation, evaluation, and or solution" (Entman 1993, p52). Thus, framing plays an important role and directly affects not only the general public in the current situations but it will also have a long-term impact on society as a whole.

As this article looks at the media framing and tones of the two daily newspapers of Nepal which can help other researchers' valuable insights into the media organizations in the coverage of the COVID19 pandemic at its initial stages. According to Pollett and Rivers (2020), coronavirus disease, 2019 (COVID-19) pandemic and our knowledge about the virus has exponentially grown since media reports of a cluster of acute respiratory infections in Wuhan, Hubei Province, China. Hence it is justified to look at the role of mass media in framing the news during the disease outbreak by emphasizing on the angle or direction of reportage. The article also identifies the tones and the priorities the media organizations have given while covering the pandemic. Along with the dominance frame used in the COVID-19 on both the newspapers.

As the media angles of presenting issues take the form of media framing to influence public perception and induce an attitudinal response, leading to positive behavioural changes. Media framing is the way in which information is presented to its audiences. Goffman was the first to concentrate on framing as a form of communication. According to Goffman (1974), frames are storytelling devices used by people to understand and translate social reality. Specifically, frames are 'schemata of interpretation,' through which people 'locate, perceive, identify, and label'.

Entman (1993) modernized the definition that Goffman has given by focusing that "to frame a communicating text is to promote certain facts of a perceived reality and make them more salient in a way that endorses a specific problem, definition, casual interpretation, moral evaluation and or a treatment recommendation (Entman, 1993).Entaman believes that by incorporating media framing with agenda setting, priming and bias, readers can easily comprehend how and why framing occurs in the media. "Agenda setting is defined as the first function of framings as it defines the problems worthy of government attention." "Priming is "the goal", the intended effect, of strategic actors" framing strategies." (Entman, 1993, p.165). When combining agenda setting and priming, it has the ability to create widespread bias. Bias is the "consistent patterns in the framing of mediated communications that promote the one side of conflicts over the use of government power (Entman, 1993, p166).

According to Gamson and Modigliani (1987) a frame is a "central organizing idea or storyline that provides meaning to an unfolding strip of events, weaving a connection among them." Framing offers specific directions for news receivers to interpret and discuss reality (Tuchman, 1978). Hence, the ways in which news about an issue or event is framed may affect audience members' perceptions of this issue or event (Iyengar, 1991; Scheufele, 1999). In this way, studying news framing is important to understand the public's perception of an issue or event.Scholars has also conducted analyses to study how mass media in different countries frame public health issues. For example, Abeysinghe and White (2010) studied how Australian newspapers framed the avian influenza pandemic. Sinaceur, Heath, and Cole (2005) studied how Mad Cow Disease was framed by French newspapers. Clarke, McLellan, and Hoffman-Goetz (2006) studied how news about HIV/AIDS was framed by two African American magazines. Shih, Wijaya, and Brossard (2008) examined how print media in the US framed public health epidemics, including mad cow disease, West Nile virus, and avian flu. 
Framing emphasizes the issue of methods through which the media streamline and present news content. Media organizations adopt framing to simplify complex issues to make room for the audience to easily understand and form opinions about the issue through text, pictures or symbols (Tolley, 2016).

Through news frames, the media provide important information and knowledge which often influence public or audience opinion and decision (Ofori-Birikorang, 2010). Framing can sway public opinion on an issue which has significant consequences for how the public views and understands an issue, and they respond to it (Chime-Nganya et al., 2017). It showcases how societal issues are portrayed and how messages are encoded with meaning by the media so that they can be easily decoded vis-à-vis existing idea (Chilisa, 2012).

Amber et al., (2013) research on framing has benefitted from some well-established frame categorisations that is generalised across issues. For example, Iyengar in Jibrin (2019) identifies episodic frames which concentrate on specific incidents or cases as different from thematic structures which focus on broader trends or context. These influence on public attitudes or reactions.

Iyengar (1991) stated that the thematic framing is the portrayal and presentation of issues through information about their systemic causes, trends and consequences. According to lyengar, this frame is often used in covering health problems. While episodic framing is the portrayal and presentation of issues through a specific event that could serve as an anecdotal exemplification of the broader issues or the story of an affected person who could put a human face on the issues (Iyengar,1991). Therefore, episodic frames tend to attribute responsibility or blame to individuals or a group rather than the greater society. Thematic frames are less personal and generally place the story in a broader societal context. Iyengar concluded that journalistic norms, such as the standards of news production, support episodic framing because episodic allows the media to simplify complex issues through anecdotal evidence.

However, focusing on the individual episode can also distract the audience from larger issues that contribute to problems or lead to the omission of solutions that could help. Additional studies of episodic versus thematic framing have determined that the news media tend to unfairly treat certain topics, such as crime, as episodes or onetime events rather than ongoing issues with solutions (Rodgers \& Thorson, 2001).

In framing, the media devote volume of coverage to a particular issue. The media through framing make an issue salient and direct audience attention to specific issues, ideas and individuals while downplaying what lies outside the frame (Boykoff \& Laschever, 2011). In terms of frame tone, Greenslade (2015) noted that much of media coverage tilt towards the negative than the positive.

This article reports a study anchored on Framing Theory. Framing as a theory is credited to Gregory Bateson as first posited in 1972. Framing Theory is a platform for the media to situate various perspectives of an occurrence that is newsworthy. It is sometimes referred to as second-level Agenda Setting because it has a close relationship to Agenda Setting theory. Framing refers to how the media organize and present information to the public on certain issues, or events and give them particular context to sway interpretation and necessitate selective influence over how members of the public view reality. Framing Theory is a philosophical postulation that provides an explanation on which news content is typically shaped and contextualized by a media outlet (Msughter \& Phillips, 2020).

According to Goffman in Jibrin (2019) frames are cognitive structures that guide the representation of events. In framing, the media devote volume of coverage to a particular issue. The media through framing make an issue salient and direct audience attention to specific issues, ideas and individuals while downplaying what lies outside the frame (Boykoff \& Laschever, 2011). The media play an agenda setting role by drawing attention to certain issues and also by framing the cause and solutions of these problems. Armstrong, Carpenter and Hojnacki (2006), in demonstrating the agenda-setting role of the media argued that the media bring certain diseases to the spotlight while keeping others hidden from the public eye.

Meijer and Kleinnijenhuis (2006), who stated that tone could take one of the following

Nepalese Journal of Development and Rural Studies, Volume, 18, 2021 
values: $-2,-1,0,1$ or 2 . This ranges from very negative to very positive. Negative terms include 'misbehaviour', 'failure' and 'ingratitude'. Examples of positive wording are 'honesty', 'satisfaction' and 'appreciation' (Kuttschreuter et al., 2011).

News media can, consciously or unconsciously, use a variety of specific frames to communicate news to audiences (Steimel, 2010). For instance, Neuman, Just and Crigler (1992) examined four dominant news frames that are applicable to multiple news contexts, namely; Conflict, Economic consequences, Morality and Human impact frames.

Valkenburg, Semetko and de Vreese (1999) added the responsibility frame and renamed the human impact frame as the human-interest frame. Research has identified the five frames in their content analyses, because journalists all over the world frequently use these frames.

In this study, the framing theory is reconstructed and borrowed the frames from Valkenburg, Semetko and de Vreese (1999) that are deemed relevant in exploring the media coverage of the initial stages of the COVID-19 pandemic.

MacMilan and Schumacher (2001) define research design as a plan that assists researchers in selecting subjects, research sites and data collection procedures to find out the answers of the research questions. It is a framework that helps researchers to strategically plan about how to conduct the research. InnamAkthar (2016) stresses that the research design should be able to answer the questions like what type of data is required, what are the sources of required data, what method of data collection is appropriate and so on. In short, research design can be called as a blueprint that dictates researchers about how one can find answers to the problems.

The outbreaks coverage in the Kathmandu Post and The Rising Nepal were analysed to allow for a comparison on framing. A quantitative content analysis is the best method to use for this study since it provides an effective way to review a text systematically to learn about the frames included in the representative sample of articles.

Entman (1993) frames are found in texts and are created by the presence or absence of certain words, phrases, stereotyped images sources or clusters of thematically reinforcing facts or judgements. At the end, content analysis can provide the method that can be used to review those words and draw conclusions using the data that is found.

The Kathmandu Post and The Rising Nepal newspapers were purposely selected based on their ownership and coverage.

Table 1. Selection and the Sampling Timeline for Newspaper Articles

\begin{tabular}{lll}
\hline SN & Case Study & Time period and Prevalence \\
\hline 01 & COVID-19 outbreak & $\begin{array}{l}\text { No of infected individuals: Nine } \\
\text { Sampling duration: 1st May- 1st July }\end{array}$ \\
& &
\end{tabular}

* Sources: Ministry of Health and Population, 2020

Table 2: Media Outlet Selection

\begin{tabular}{|c|c|c|}
\hline S.N & Media outlet & Justification for selection \\
\hline 01 & The Kathmandu Post & $\begin{array}{l}\text { - Widest circulated broadsheet English Daily in Nepal } \\
\text { - Nepal's first privately owned English Broadsheet } \\
\text { daily } \\
\text { - Well-known for its longer investigative pieces, } \\
\text { analyses and explainers. }\end{array}$ \\
\hline $\mathbf{0 2}$ & The Rising Nepal & 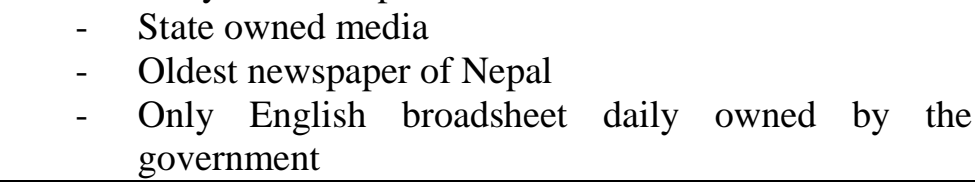 \\
\hline
\end{tabular}

Nepalese Journal of Development and Rural Studies, Volume, 18, 2021 
Sources: Press Council Nepal, 2020 (https://www.presscouncilnepal.gov.np).

Both of the selected newspaper are prominent national newspaper and are particularly noted for their larger role according to the latest categorizations of newspapers by Press Council Nepal (PCN, 2020). The Kathmandu post is the first private-run-English language broadsheet in the country. 'The Kathmandu post' is categorized as 'A+' English medium newspaper. The content of newspaper contains Politics, Business, Sports, Editorial, Op-ed etc.

The Rising Nepal is a state owned medium daily newspaper published by Gorkhapatra Corporation (media house owned and operated by the Government of Nepal) throughout the country. The information about the selected newspaper is retrieved from the website of the Kathmandu Post and The Rising Nepal. The selected study period for the analysis is noticeably marked the initial stage of the COVID-19 pandemic in Nepal. The database includes feature and news articles published in the two newspapers. Stories published in the newspaper of the selected media outlet were studied during the research period. The search phrases like "COVID-19 + Kathmandu post", "COVID-19 + the rising Nepal" were used to search the articles. E-paper published by both the newspapers were analysed to conduct the research thoroughly.

\section{Methodology}

The codebook of this analysis is presented in three parts. First of all, the existing frames in the article were coded to create an overview of the content with regard to the media coverage. This part of the codebook is based on the conceptual framework of Semetko and Valkenburg (2000). As the framework of Semetko and Valkenburg (2000) has been used by several researchers to investigate media coverage with regard to crises (An \& Gower, 2009; D'Haenens \& de Lange, 2011; Nijkrake, Gosselt \& Gutteling, 2014), so this framework is selected. The framework involves the five previously mentioned frames: the human-interest frame, the responsibility frame, the conflict frame, the economic consequences frame and the morality frame. For each news article, the presence and content of the preceding frames were analysed with the use of a list of questions, which each characterize one of the five news frames.

The original framework of Semetko and Valkenburg (2000) consists of 20 questions, but five items not related for the pandemic articles and one item related to visual information was removed, because to make the research simple as well as this research does not look into the images, but only the text. The main stakeholder was coded in order to determine the tone of the article. The determination of the tone was easier to find out on the basis of the main stakeholder of the article. Eight commonly used stakeholder categories were identified during the pre-test: Migrant workers, Government, Women and child, World Health organizations, Banks, health workers, political leaders, civilians and the ninth addition was 'other'. For each article, the most important stakeholder was determined. Finally, the tone was coded. This was done based on the positive or negative wording regarding the main stakeholder in the article.

The five-point 'tone' scale was based on the research of Meijer and Kleinnijenhuis (2006), who stated that tone could take one of the following values: $-2,-1,0,1$ or 2 . This ranges from very negative to very positive. Negative terms include 'misbehaviour', 'failure' and 'ingratitude'. Examples of positive wording are 'honesty', 'satisfaction' and 'appreciation' (Kuttschreuter et al., 2011).Articles with a neutral tone were factual pieces that avoided strong wording, personal statements or anecdotes (Miller, Tyler \& Mor, 2014).After the representations of a sample of articles were selected from each newspaper, the obtained data is analysed by a coding method of pre- designated themes found in the past literature of media coverage during the crisis like pandemic. Each article was coded based on five frames: Humaninterest frame, responsibility frame, Morality, Conflict, economic consequences.

After the data analysis, the study aims to evaluate the dominant news frames used in reporting COVID-19 in Nepal, including the consistency that has been followed in Nepali media and also the suppressed biases in the selected media outlets. 


\section{Findings}

The frequency of the news frames used in the media coverage is presented in Table 4. as stated before, an article can contain multiple frames. Two frames dominate the media coverage of the pandemic: the economic consequences frame $40 \%$, and the responsibility frame $25 \%$, followed by human interest frame $11 \%$. Further $12 \%$ of stories contained the conflict frame, followed by the morality frame, which was present in $12 \%$ of articles. All five media frames will be discussed in detail with the use of their characteristics, which could also be found in Table 4. One article can contain multiple characteristics of a frame at the same time.

Table 3. The Number of F rames Covered by 'The Kathmandu Post' and 'The Rising Nepal'.

\begin{tabular}{|c|c|c|}
\hline Media coverage & Media coverage & Characteristics \\
\hline Economic consequences frame & $40 \%$ & \\
\hline $\begin{array}{l}\text { Does the story mention financial losses } \\
\text { or gains, now or in the future? }\end{array}$ & & $60 \%$ \\
\hline $\begin{array}{l}\text { Does the story mention cost or the } \\
\text { degree of expenses involved? }\end{array}$ & & $22 \%$ \\
\hline $\begin{array}{l}\text { Does the story refer to economic } \\
\text { consequences of pursuing or not } \\
\text { pursuing a course of action? }\end{array}$ & & $18 \%$ \\
\hline - Human interest frame & $16 \%$ & \\
\hline $\begin{array}{l}\text { Does the story provide a human example } \\
\text { or 'human face' on the issue or } \\
\text { problem? }\end{array}$ & & $80 \%$ \\
\hline $\begin{array}{l}\text { Does the story emphasize how } \\
\text { individuals and groups are affected by } \\
\text { the issue or problem? }\end{array}$ & & $15 \%$ \\
\hline $\begin{array}{l}\text { Does the story employ adjectives or } \\
\text { personal vignettes that generate feelings } \\
\text { of outrage, empathy or caring, or } \\
\text { sympathy or compassion? }\end{array}$ & & $5 \%$ \\
\hline - Responsibility frame & $20 \%$ & \\
\hline $\begin{array}{l}\text { Does the story suggest that some level of } \\
\text { government has the ability to alleviate } \\
\text { the issue or problem? }\end{array}$ & & $56 \%$ \\
\hline $\begin{array}{l}\text { Does the story suggest solution(s) for the } \\
\text { problem or issue? }\end{array}$ & & $20 \%$ \\
\hline $\begin{array}{l}\text { Does the story suggest that the problem } \\
\text { requires urgent action? }\end{array}$ & & $24 \%$ \\
\hline $\begin{array}{l}\text { - Conflict } \\
\circ \text { Does the story reflect disagreement } \\
\text { between parties-individuals-groups- } \\
\text { countries? }\end{array}$ & $10 \%$ & $47 \%$ \\
\hline
\end{tabular}

Nepalese Journal of Development and Rural Studies, Volume, 18, 2021 


\begin{tabular}{|c|c|c|}
\hline Media coverage & Media coverage & Characteristics \\
\hline $\begin{array}{l}\text { Does the story refer to two sides or to } \\
\text { more than two sides of the problem or } \\
\text { issue? }\end{array}$ & & $53 \%$ \\
\hline $\begin{array}{l}\text { - Morality } \\
\text { Does the story contain any moral } \\
\text { message? }\end{array}$ & $14 \%$ & $84 \%$ \\
\hline $\begin{array}{l}\text { Does the story offer specific social } \\
\text { prescriptions about how to behave? }\end{array}$ & & $15 \%$ \\
\hline $\begin{array}{l}\text { D Does the story make a reference to } \\
\text { morality, God and other religious tenets? }\end{array}$ & & $1 \%$ \\
\hline
\end{tabular}

Source: Kathmandu Post and Rising Nepal, 2020

The total number of articles published during the study period is 280 . The commercially owned 'The Kathmandu Post' has covered more news of the pandemic then the state owned 'The Rising Nepal' within the selected period of time. The Kathmandu Post total covered 150 news which is 54\% and The Rising Nepal covered 130 news which is $46 \%$. Within these data, we have identified the dominant frame in both of the selected newspapers in following figures.

\section{Figure 1. Reporting on COVID-19 in 'The K athmandu Post' and 'T he R ising Nepal'}

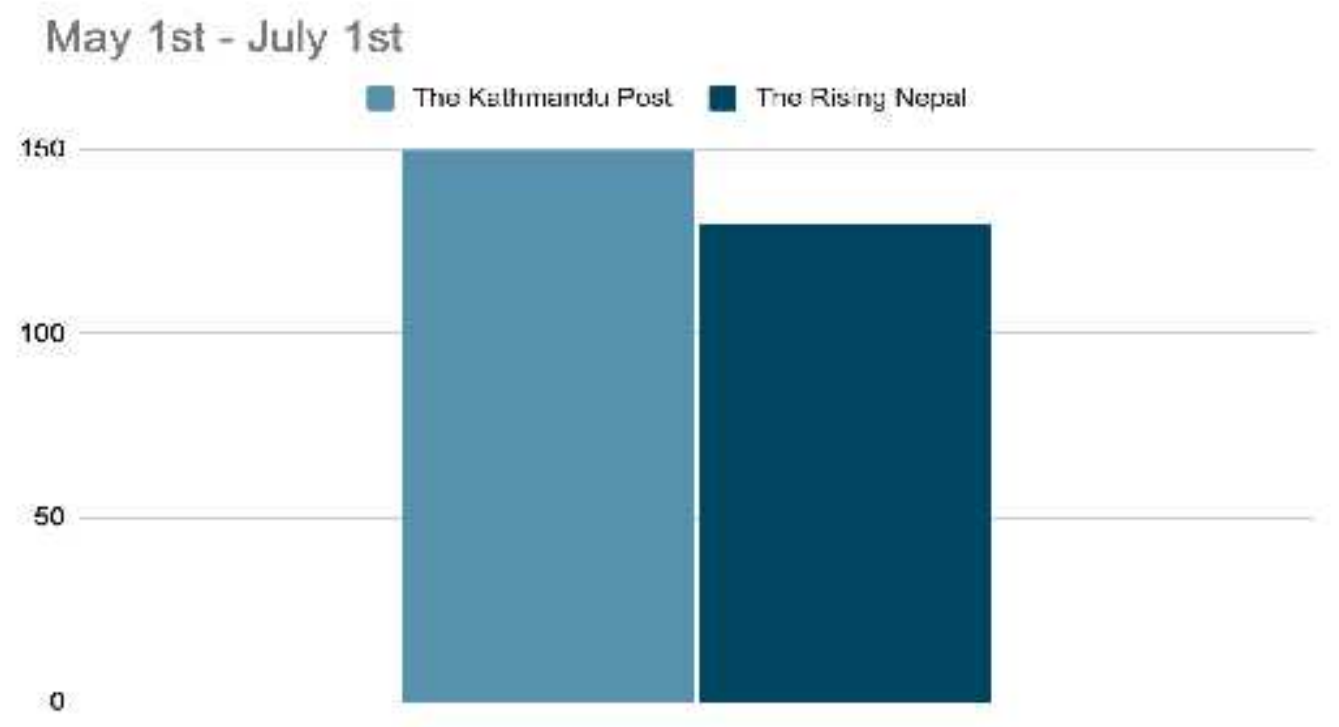

Sources: The Kathmandu Post and The Rising Nepal: 1st May to 1st July- 2020

'The Kathmandu Post' prioritized more economic consequences framing in the published articles. Articles related to migrant workers' loss of jobs due to pandemic and shut down of businesses led to huge economic downfall during pandemic was covered frequently by following the economic consequences frame. Responsibility framing was placed as second priority in the face of the COVID-19. "Nepali embassies ill treatment of workers during pandemic, health workers treated unfairly, stigma against the COVID-19 patients were covered as responsibility framing. In third, human-interest framing was placed in the third important farming in the Kathmandu post followed by the equal number of conflict and morality framing. 


\section{Figure 2. Dominant Frame in 'The K athmandu Post'}

\section{The Kathmandu Post}

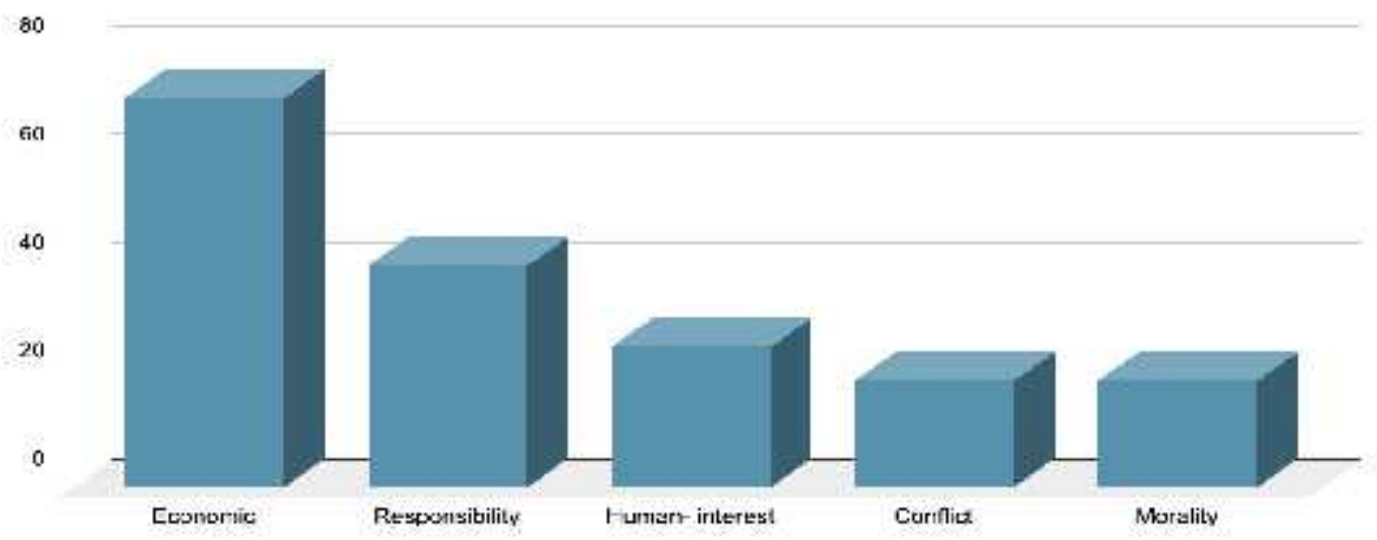

Sources: The Kathmandu Post: 1st May to 1st July- 2020

The Rising Nepal' had also covered the majority of news coverage on the economic frame followed by the responsibility framing. There is not a huge gap in between economic framing and responsibility framing. However, conflict framing such as health sectors carelessness by the government was covered very less unlike The Kathmandu Post. Conflict framing regarding government preparedness of the diseases were not covered by The Rising Nepal. Thus, the lowest framing is of conflict framing. 
Figure 3. Dominant frame in 'T he Rising Nepal'

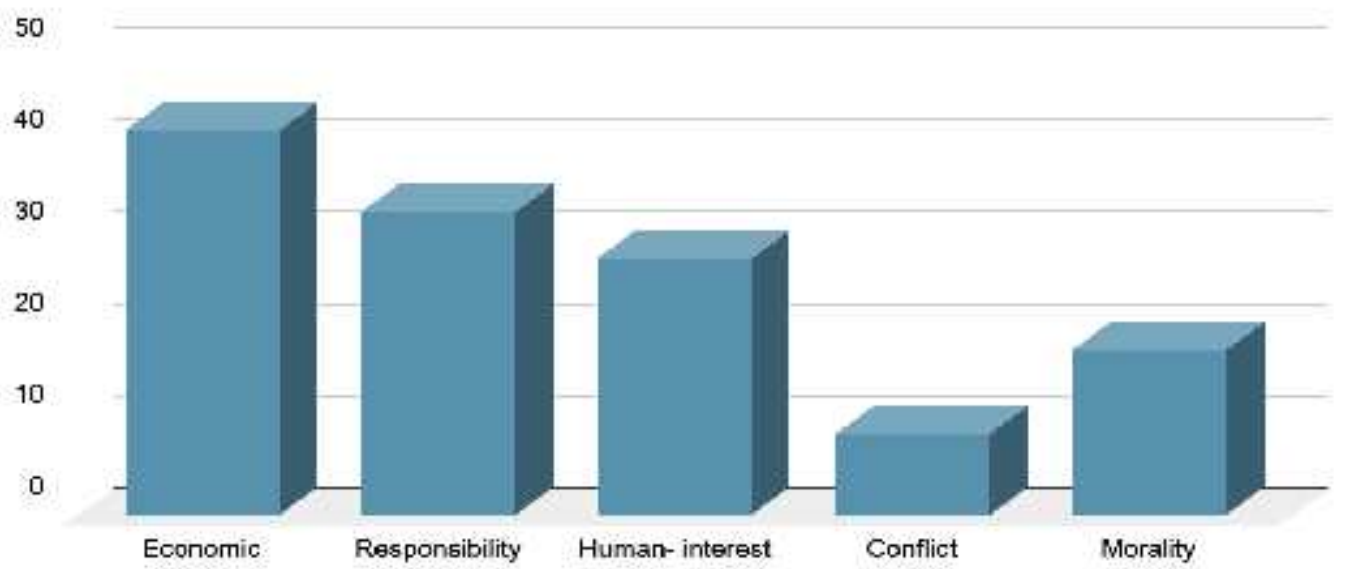

Sources: The Rising Nepal: 1st May to 1st July- 2020

As explained above, the coding of the main stakeholder was primarily intended to determine the tone of the media coverage. Even though it is not possible to combine the results of the frames and the stakeholder one-to-one, it remains interesting to observe the tone of the articles where a certain stakeholder was present. The Kathmandu Post had covered all together 137 news articles in a very negative frame, 28 neutral, 13 positive, 2 very positive. The migrant workers business and political leader's articles were framed negatively.

Figure 4. The Use of Tone in The Kathmandu Post per Type of Stakeholder

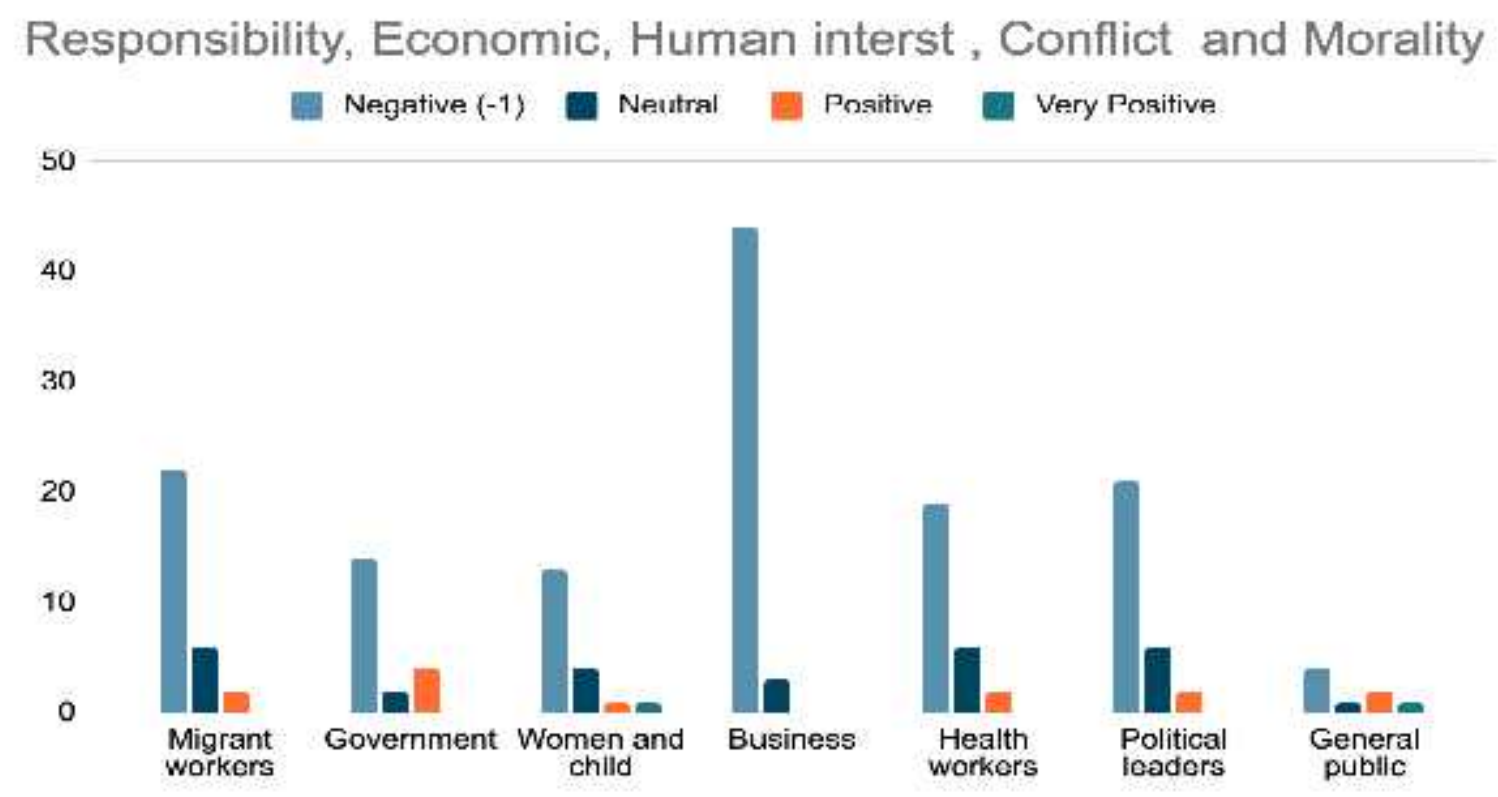

Sources: The Kathmandu Post 1st May to 1st July- 2020

The Rising Nepal had a majority of neutral and negative tone in the coverage. The neutral tone was mostly followed by the responsibility framing. Hence, The Rising Nepal had the majority of economic framing with the neutral tone. While the Kathmandu Post has majority of economic framing coverage with the negative framing. 
Figure 5. The Use of Tone per Type of Stakeholder in the Rising Nepal
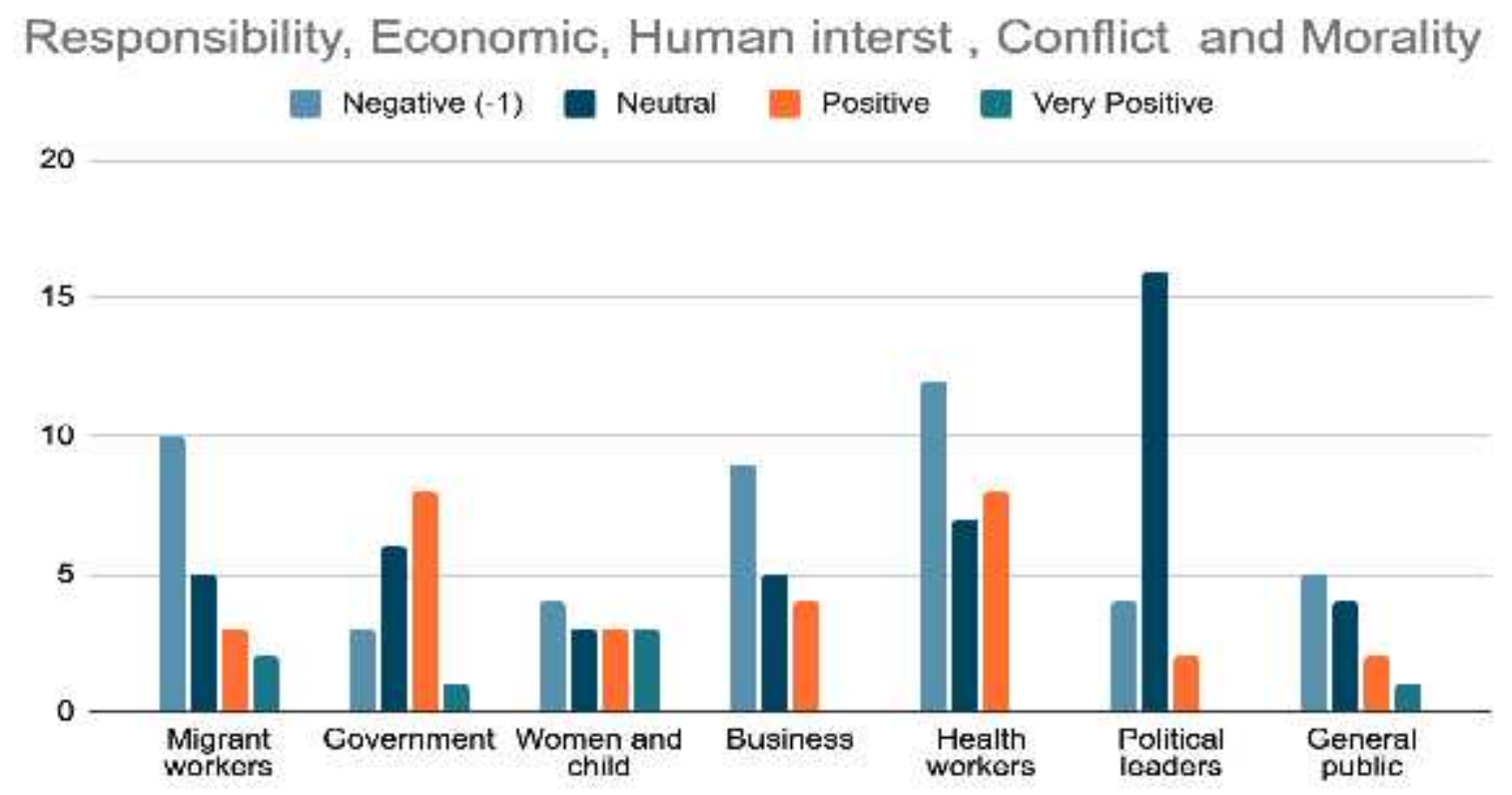

Sources: The Rising Nepal 1st May to 1st July- 2020

The media framed COVID-19 its economic consequences in most of the articles published between May 1st to July 1st. The Kathmandu post had the greatest number of articles that included an economics theme. The economic consequences frame often appeared in the form of migrant workers returning back to their home country, the unemployment rate, and market shutdown during lockdown, job cut, job losses, the halted big international project, fearing it might lead to the greatest downfall in the economy. The tone of the media coverage regarding the COVID-19coverage is negative in both the newspaper, The Kathmandu Post and The Rising Nepal. The tone is negative more in the Kathmandu Post in comparison with the Rising Nepal. The conflict issues with political leaders regarding the COVID-19is excessively high in The Kathmandu Post and very less at The Rising Nepal.

\section{Conclusion}

The major objective of the analysis was to explore how the media place responsibility for COVID-19. The findings provide several insights into how the media frame the COVID-19, the tone of the stories and the implications of the tone while presented as news. It is evident from the discussion that the media is the powerful tool for informing the key messages and behavioural changes. The media irrespective of locations and ownership should present issues in a suitable way. This study concludes that COVID-19 pandemic coverage comes up with different important narratives for different newspapers. Despite being the problem common. The media have covered the issues giving favour to economic framing. But looking at the health infrastructures of our country, responsibility framing is the most needed frame that the media should follow during such a crisis. We can see how the media reporting COVID-19 pandemic sway narratives.

While focusing on the economic perspective with the more negative tone, the general population, those who do not have access to the right kind of information regarding health might be confused. Every citizen has the right to information and to understand the information without the presence of sensationalism and beyond propaganda.

The frames follow the majority of negative tones in the Kathmandu Post. This implies that we continue to blame others, in this way we never learn to be responsible. This shows that the general 
population might didn't see the potential risk of COVID-19 because the negative coverage which is focused on economy might confuse them. Therefore, the media would continue to frame issues irrespective of what perspectives suit them. Hence, we can conclude that the media coverage of the COVID-19 pandemic is most frequently framed in terms of economic consequences rather than focusing to improve the quality of life. The use of the responsibility, human interest, conflict and economic consequences frames differs significantly among stakeholders.

The Political group (consisting of the Nepal government politicians) responsibility towards the situation was covered more with the conflict frame with a negative tone in the Kathmandu post while in The Rising Nepal, it was very low, which can be found above. Migrant workers issues should be covered with the responsibility frame rather it was found that migrant workers were considered only as a source of remittance and were covered with economic frame.

The articles in which the conflict frame is present are the most negatively written, compared with articles where other frames are present. There is a significant positive correlation between the human-interest frame and tone, and a significant negative correlation between the responsibility frame and tone and the conflict frame and tone.

The tone of the media coverage differed between the two newspapers, but both the newspapers viewed COVID-19 as an economic crisis. The findings of the research will help the readers to expand their understanding of the topic and how the media have been covering the pandemic. As well as it will also further expand the need for the research in the subject of media framing amid the pandemic.

Since both the newspapers have their own style of reporting and choosing frames with respective tone with the aim to inform the public during these uncertain times. But, the way of choosing frames and selecting tones sometimes might provide inaccurate information to the public. There are good and bad elements to the way news has been covered during pandemic. Time and again the media have been reporting the story in a binary manner. Headlines across the media have been buzzling with stories on the pandemic. It seems quite worrying when the media portrays it in a negative tone and diverts the issues by focusing on economics and more on negative aspects while many people are scumbled by the diseases. The information should not be diluted with the information that is worrying.

It is noticeable that the media in respect of the COVID-19hyped the consequences focusing more on the economic perspective of the virus. Investigating media coverage of infectious disease epidemics should be a high priority for media research and risk analysis.

\section{References}

Abeysinghe, A.\& White, K. (2010). Framing disease: The avian influenza pandemic in Australia.Health Sociology Review, 19(3), 369-381.

Angelo, P. D. (2002): News framing as a multi-paradigmatic research program: A response to Entman.Journal of Communication 52(4), 870 - 888

Beaudoin, C. E. (2007). SARS news coverage and its determinants in China and the US. International Communication Gazette, 69, 509-524.

Boykoff, J.\&Laschever, E. (2011). The tea party movement, framing, and the US media. Social Movement Studies, 10(4), 341-366.

Brewer, P. R., Graf, J.\&Willnat, L. (2003). Priming or framing media influence on attitudes toward foreign countries. Gazette, 65(6), 493-508.

Center for Disease Control and Prevention [CDC]. (2018). History of 1918 Flu Pandemic. https://www.cdc.gov.

Center for Disease Control and Prevention [CDC]. (2020). Coronavirus.https://www.cdc.gov/coronavirus/2019-ncov/index.html. Accessed March 29, 2020.

Chilisa, B. (2012). Educational research within postcolonial Africa: A critique of HIV/AIDS research in Botswana. International Journal of Qualitative Studies in Education, 18(6), 659-684. 
Chioma R Chime-Nganya, C., Daniel ToochukwuEzegwu, D. A. Ezeji. (2017). Analysis of Nigerian newspapers framing of President MohammaduBuhari's medical leave to United Kingdom. Journal Media and Communication Currents, 1(2), 39-56.

Clarke JN, McLellan L.\&Hoffman-Goetz L. (2006). The portrayal of HIV/AIDS in two popular African American magazines. J Health Commun. 2006,11(5), 495-507.

Elizabeth, M., Armstrong, E.M., Carpenter, D. \&Hojnacki, M. E. (2006).Whose deaths matter? Mortality, advocacy, and attention to disease in the mass media. Journal of Health Politics Policy and Law, 31(4), 729-72

Entman, R. (1993). Framing: Toward clarification of a fractured paradigm. Journal of Communication.Journal of Communication, 43 (4), 51-58.

Gamson, W. A.\& Modigliani, A. (1989). Media discourse and public opinion on nuclear power: A constructionist approach. American Journal of Sociology, 95(1), 1-37.

Goffman, E. (1974). Frame analysis. Boston: Northeastern University Press.

Greenslade, R. (2015). Where media fails on the reporting of migrants and refugees.https://www.theguardian.com/media/greenslade/2015/dec/17/where-media-fails-on-thereporting-of-migrants-and-refugees. Accessed on 29 March 2020.

Hallahan, K. (1999). Seven models of framing: Implications for public relations. Journal of Public Relations Research, 11(3), 205-242.

https://www.cdc.gov/flu/pandemic-resources/1918-commemoration/1918-pandemic-history.htm. Accessed March 29, 2020.

International Labour Organization [ILO].(2020). Impact of the COVID-19crisis on loss of Jobs and hours among domestic workers.https://www.ilo.org/global/topics/domesticworkers/publications/factsheets/WCMS_747961/lang--en/index.htm. Accessed on 29 March 2020

Iyengar, S. (1991). Is anyone responsible? How television frames political issues. Chicago: University of Chicago Press.

Jibrin, A. M.\&Jimoh, I. (2017) CNN and Aljazeera framing of the Boko Haram conflicts in Nigeria (January-December 2014). International Journal of Communication: 119-135.

Kuttschreuter, M.,Gutteling, J. M.\& Maureen de Hond, M. (2011). Framing and tone-of-voice of disaster media coverage: The aftermath of the Enschede fireworks disaster in the Netherlands.Health, Risk \& Society, 13:3, 201-220.

Meijer, M.\&Kleinnijenhuis, J. (2006). News and corporate reputation: Empirical findings from the Netherlands. Public Relations Review, 32(4), 341-348.

Miller, E. A., Tyler, D., Rozanova, J.\&Mor, V. (2012). National newspaper portrayal of U.S. nursing homes: Periodic treatment of topic and tone. The Milbank Quarterly, 90, 725-761.

Msughter, A. E., \& Phillips, D. (2020). Media framing of COVID-19pandemic: A study of daily trust and vanguard newspapers in Nigeria.International Journal of Health, Safety and Environment (IJHSE). 6(05), 588-596

Nisbet, M. C. (2009). Communicating climate change: Why frames matter for public engagement, environment.Science and Policy for Sustainable Development, 51(2), 12-23.

Organization for Economic Development and Cooperation [OECD]. (2020). OECD Policy Responses to Coronavirus (COVID-19): The territorial impact of COVID-19: Managing the crisis across levels of government.https://www.oecd.org/coronavirus/policy-responses/the-territorial-impact-ofCOVID-19-managing-the-crisis-across-levels-of-government-d3e314e1/ . Accessed on 29 March 2020.

Ofori-Birikorang, A. (2010). Promoting a new health policy in the Ghanaian media: Newspaper framing of the national health insurance scheme from 2005- 2007. Unpublished doctoral dissertation, Ohio University, Athens, $\mathrm{OH}$. 
Ophir, Y. (2018).Spreading news: The coverage of epidemics by American newspapers and its effects on audiences - A crisis communication approach. Publicly Accessible Penn Dissertations. 2787.https://repository.upenn.edu/edissertations/2787. Accessed on 29 March 2020.

Pan, Z., \&Kosicki, G. M. (1993). Framing analysis: An approach to news discourse. Political communication, 10(1), 55-75.

Pollett, S. \& Rivers, C. (2020). Social media and the new world of scientific communication during the COVID-19 pandemic.Clinical Infectious Diseases, 71(16), 2184-2186.

Press Council Nepal (PCN) (2020). Study repot on the impact of covid-19 on Nepali media 2020.https://www.presscouncilnepal.gov.np/en/study-repot-on-the-impact-of-COVID-19-onnepali-media-2020/. Accessed on 29 March 2020.

Rodgers, S. \& Thorson, E. (2017). Digital advertising: theory and research. New York, NY: Routledge.

Scheufele, D. A. (1999). Framing as a theory of media effects. Journal of Communication, 49(1), 103122.

Semetko, H. A.\&Valkenburg, P. M. (2000). Framing European politics: A content analysis of press and television news.Journal of Communication, 50(2), 93 - 109

Shih, T.,Wijaya, R.\& Brossard, D. (2008). Media coverage of public health epidemics: Linking framing and issue attention cycle toward an integrated theory of print news coverage of epidemics. Mass Communication and Society, 11(2), 141-160.

Sinaceur, M., Heath, C., \& Cole, S. (2005). Emotional and deliberative reactions to a public crisis: $\operatorname{mad}$ cow disease in France. Psychological Science, 16(3), 247-254.

Sreedharan, C., Thorsen, E., Upreti, L. \& Sharma, S., (2020). Impact of COVID-19 on journalism in Nepal. Project Report. Tripureshwor, Kathmandu: Nepal Press Institute.http://eprints.bournemouth.ac.uk/34441/

Tolley, E., Ulin, P., Mack, N., Robinson, E. \&Succop, S. (2016). Qualitative methods in public health: A field guide for applied research. San Francisco, CA: Wiley.

Tuchman, G. (1978). Making news. New York: Free Press.

Valkenburg, P. M., Semetko, H. A., \&deVreese, C. H. (1999). The effects of news frames on readers' thoughts and recall. Communication Research, 26, 550-569.

World Health Organization [WTO].(2020). Coronavirus disease (COVID19).https://www.who.int/health-topics/coronavirus\#tab=tab 1. Accessed on 29 March 2020. 